DOI https://doi.org/10.32405/2522-9931-7(36)-161-178

Удк 159.96

\author{
Soorena Sardarzadeh, \\ Ph.D student at Department of Psychodiagnostics \\ and Clinical Psychology, Faculty of Psychology \\ Taras Shevchenko National University, \\ Kyiv, Ukraine \\ soorena.sardarzadeh@gmail.com
}

\title{
DOMINANT COGNITIVE AND EMOTIONAL SCHEMAS IN DEPRESSION AND ANXIETY DISORDERS
}

\begin{abstract}
Anxiety and depression disorders are the most prevalent disorders that which cause considerable disorders, overusing sanitation care services and hyperactivity disorder. Based on cognitive perspective it is mental damage caused by creation and stability of early maladaptive schemas and patterns of habitual thinking is very popular and comprehensive that identify vulnerability kind. Many researches have been performed on reasons of anxiety and depression disorders creation so this study aimed at investigating role of dominant cognitive and emotional schemas in depression and anxiety disorders. Current study is causative-comparative study out of which 109 people are suffered from different kinds of anxiety disorders and 208 patients are suffered from depression disorders. Tastes were evaluated after semistructured interview based on of DSM-IV-TR, (SCID-I) by Young early maladaptive schemas (short form) and Leahy emotional schema Scale (LESS). In order to analyze data one-way variance analysis was used. According to the results, emotional schemas of $\mathrm{v}$ has role in creation of all anxiety disorders. However, rational emotional schema has no role in creation of socio phobia disorders, personified phobias, obsessive compulsive disorder and anxiety disorder. In cognitive schemas contexts in all levels of anxiety disorders, all domains of cognitive schema are inefficient specially disconnection and rejection Domain. Emotional schemas of depressed people were analyzed and indicated that emotional schemas of guilt and validation by others are dominant pattern in explanation of depression disorders. Out of cognitive schemas, dependence/incompetence cognitive schemas and unrelenting standards / hypercritical can anticipate depression.

The expediency of training clinical psychologists to work with persons with depressive and anxiety disorders based on the study of their dominant cognitive and emotional schemes is stated. Such training can be carried out both in the process of training psychologists in institutions of higher education, and in conditions of postgraduate education.
\end{abstract}


Вісник післядипломної освіти. Випуск 7(36) «Серія «Соціальні та поведінкові науки» https://doi.org/10.32405/2522-9931

Key words: depression disorders; emotional disorders; young cognitive schemas; Leahy Emotional Schema Scale; early maladaptive schemas.

\section{INTRODUCTION / ВCTУП}

Statements of problem. Anxiety disorders are the most prevalent mental disorders. National study of different disorders reported that out of 4 American with minimum eligible standards one individual has a mental disorder and prevalence rate in 12 mouths is $17 / 7 \%$. Females (30/5 prevalence rate in lifespan) most males $(19 / 2$ prevalent rate may be suffered from anxiety disorder [1]. Anxiety is a condition that is identified with sense of panic and it is along with physical signs such as hyperactivity of autonomic nervous system. anxiety has effect on cognitive performance and it has inclination to create disorder in cognition process. anxiety is different with fear that is just a response to an identified risk. Conversely, anxiety is response to unknown treatment and it is vague and derived from confliction [1]. Diagnostic categorization of anxiety disorders has provided complete information related to anxiety disorders in diagnostic and statistical instructions of mental disorders, fourth edition (DSM-IV-TR, 2000) which includes panic disorder with or without agoraphobia, or agoraphobia without panic, social phobia, professional phobia, obsessive compulsive disorder and anxiety disorder, PTSD, and acute mental pressure disorder, and a generalized anxiety disorder [1].

Depression is the most prevalent psychological disorders so that it is called psychological disorders coldness [2], [10] and it the most expensive disorder [3]. Depression in DSM-IV-TR is along with energy and interest reaction, guilt, concentration difficulties, anorexia, death thoughts and suicide which its signs include change in activity level, cognitive disabilities and language and stable activities. Aperson with on two weeks period must have these signs [1].

Analysis of recent research and publications. Robert L. Leahy (2002) Three theoretical models of the relationship between cognition and emotion are examined: a) ventilation theory (i.e., the greater expression of emotion, the better the outcome), b) emotionally focused therapy (i.e., activation, expression, and validation of emotion facilitate acceptance and self-understanding), and c) a cognitive model of emotional processing (i.e., individuals differ in their conceptualization and strategies in responding to emotion). A self-report assessment of emotional schemas reflecting 14 dimensions related to cognitive processing and strategies of emotional response is presented. Fifty-three adult psychotherapy patients were assessed and their responses on the emotional schemas evaluation were correlated with the Beck Depression Inventory and the Beck Anxiety Inventory. There was strong support for a cognitive model of emotional processing. Depression was related to greater guilt over emotion, expectation of longer duration, greater rumination, and viewing one's emotions as less comprehensible, less controllable, and as different from the 
emotions others have. Anxiety was related to greater guilt over emotion, a more simplistic view of emotion, greater rumination, viewing one's emotions as less comprehensible, less acceptance of feelings, viewing emotions as less controllable, and as different from the emotions others have. Dimensions related to the strict ventilation model - such as validation, numbness, and expression - were not related to depression or anxiety, although acceptance of feelings was related to less anxiety. Support was found for the emotional-focus model. Validation was related to less guilt, less simplistic ideas of emotion, expectation of shorter duration, less rumination, and to viewing emotion as more comprehensible, more controllable, more similar to emotions of others, and more acceptance of feelings.

Camara \& Calwit (2012) studied the mediation of non-adaptive schemes in stressful events for student worries and depression. The results have shown that the existence of abandonment schemes, emotional deprivation, defect and failure can predict the symptoms of depression in stressful events.

\section{AIM AND TASKS / META TA ЗАВДАННЯ}

This study aimed at investigating role of dominant cognitive and emotional schemas in depression and anxiety disorders.

\section{Practical goal:}

\section{The purpose of this article:}

- Identify primary vulnerabilities to depression and anxiety disorders based on patient schemas and prevention of depression and anxiety disorders based on schemas.

- Treating patients with depression and anxiety base on Schema Therapy.

- Facility of diagnosis of depression and anxiety disorders by using cognitive and emotional schemas questionnaires.

- Identify depression and anxiety traits in adolescents and young people before becoming depression and anxiety disorders.

\section{Objectives \& Hypotheses:}

- There is a difference between the emotional schemas of depression and non-depression people.

- There is a difference between the cognitive schemas of depression and non-depression people.

- There is a difference between the emotional schemas of anxiety and nonanxiety people.

- There is a difference between the cognitive schemas of anxiety and nonanxiety people. 
Вісник післядипломної освіти. Випуск 7(36) «Серія «Соціальні та поведінкові науки» https://doi.org/10.32405/2522-9931

\section{THE THEORETICAL BACKGROUNDS / TEOPETИЧНI ОСНОВИ ДОСЛІДЖЕННЯ}

Each mental disorders with habitual thought samples and schemas are very popular and comprehensive which clarify vulnerability type that is related to that disorder [4], [10], and [21]. In depression schemas can be tracked from automatic thoughts [10], [16], [19] believes that some schemas might be main core of main chronic disorders of I axis, personality disorders and lighter cognitive problems. For more accurate study, Young specified some schemas which are called Early Maladaptive Schema (EMS). EMS is set of early inefficient experience with people in immediate environment of child [14] and it has effect on whole life of a person. It is believed that each schema includes components of cognition, affection and interpersonal relationship.

Emotions can be tacked in all experience of people. In all behaviors, relationships, and response of people to the situations, emotions derived from emotional schemas is observable [28], [10]. In emotional schemas model, high efforts put on accentuate emotions and strategies of emotional process [20] and it emphasize on emotions and plans by which combining core beliefs with emotional evaluations that specifies this assessment and interpretation of a person compatibility with that condition [28].

There are different points of view on explaining the etiology of depression disorders. Model «Therapy Based on Emotional Schemes» (MTS) is a metacognitive or meta-experience model of emotions in which emotions are part of the social cognitive function [22]. This model was first developed by Robert Lehi [20] on the basis of the theory of individual psychology (Adler and Yang, 1990, Beck et al., 1999). According to MTS, people with non-adaptive emotional patterns tend to rely on certain emotions and avoid using the strategy [23].

\section{RESEARCH METHODS / МЕTОДИ ДОСЛІДЖЕННЯ}

It a post-facto research that after preparing Young's questionnaire has referred to centers psychologists and psychiatrists' office and with permission from professionals and after obtaining written consent from patients, people with anxiety disorders and depressive disorders were under investigation. After diagnosis by a psychologist or psychiatrist on the basis of criteria (DSM-IV-TR) was placed on the patients and for determining the type of anxiety disorders and depressive disorders was used of the semi-structured interview based on the SCIDI (DSM-IV-TR). Then It was explained to them about the completing the questionnaires and completed by them. After distributing questionnaire in 7 psychology and psychiatry clinics, the people with anxiety disorders were identified; then, the results were examined by analysis of variance to assess significant differences in means for various types of anxiety disorders. 


\section{RESEARCH RESULTS / РЕЗУЛЬТАТИ ДОСЛІДЖЕННЯ}

Table 1

Comparing emotional schemas means of depressed people

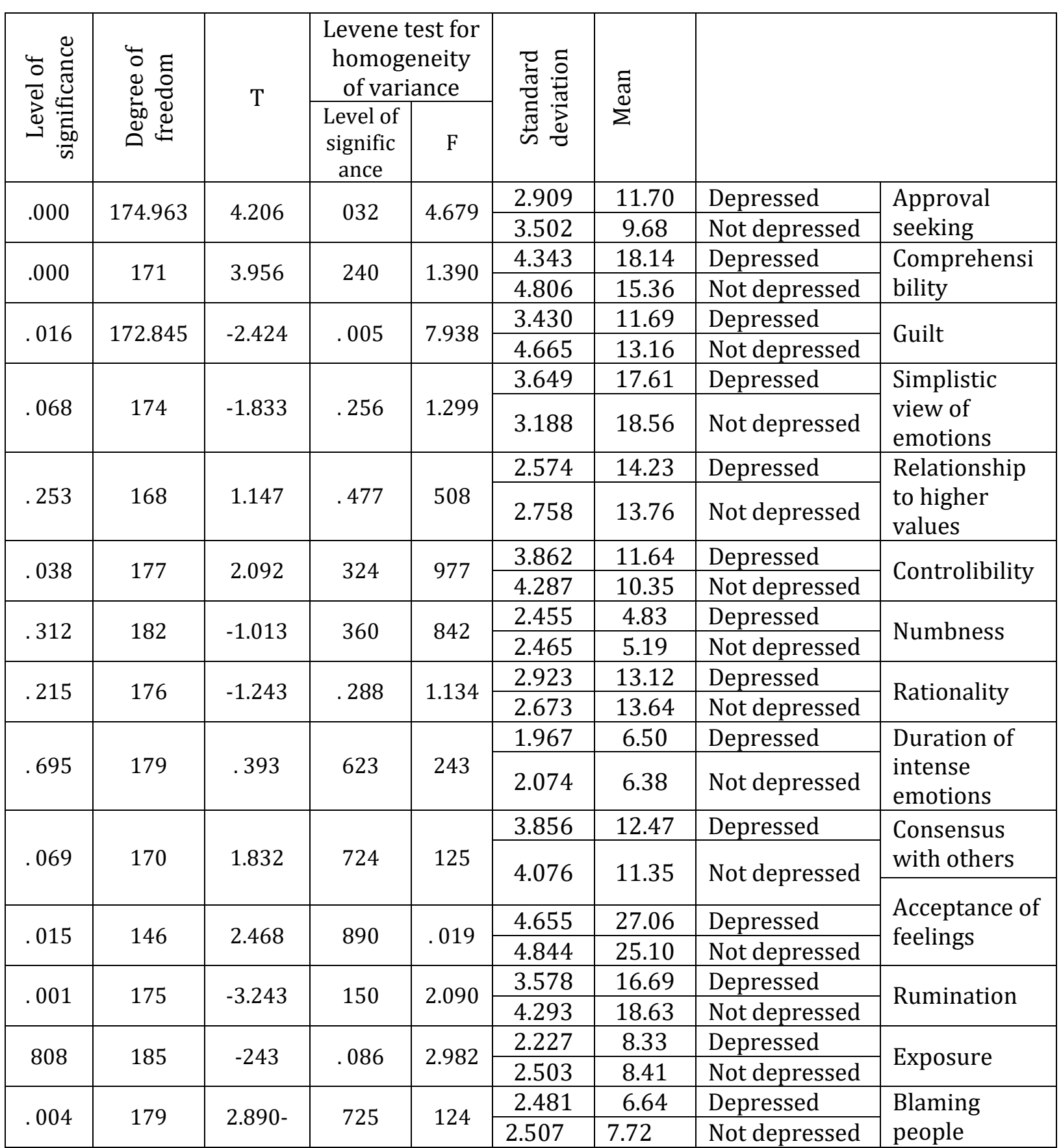


Table 2

Comparing cognitive schemas mean for depressed people

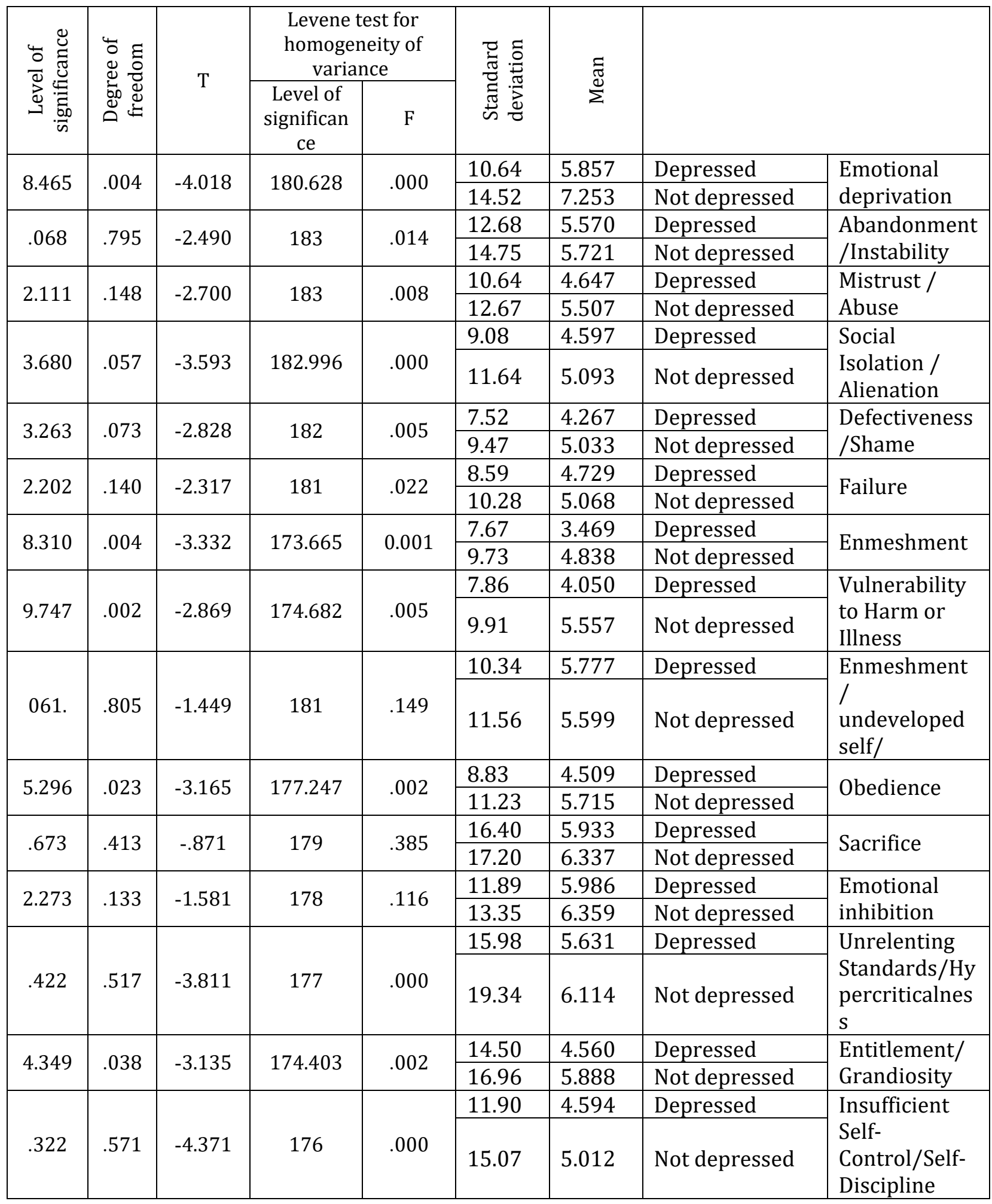


Table 3

Cognitive schemas domains in total sample of anexiety disorders

\begin{tabular}{|c|l|l|}
\hline $\begin{array}{c}\text { Schemas } \\
\text { domains }\end{array}$ & Mean & \multicolumn{1}{|c|}{ Standard deviation } \\
\hline 20.198 & 56.32 & Disconnection and Rejection \\
\hline 12.461 & 37.24 & Impaired Autonomy \\
\hline 6.654 & 29.08 & Other-directedness \\
\hline 8.981 & 29.93 & Other-directedness \\
\hline 8.353 & 32.55 & Avoidance / hypervigilance \\
\hline
\end{tabular}

As it is clear in table 3, in all anexiety disorders, disconnection and Rejection. Has maximum mean and it is considered as an ineficient schema.

Table 4

Emootional schemas in total sample of anxiety disorders

\begin{tabular}{|c|c|l|}
\hline $\begin{array}{c}\text { Emotional } \\
\text { schemas }\end{array}$ & Mean & \multicolumn{1}{c|}{ Standard deviation } \\
\hline 2.047 & 10.01 & Validation by others \\
\hline 4.039 & 7.72 & Comprehensibility \\
\hline 3.822 & 8.62 & Guilt \\
\hline 3.235 & 11.75 & Simplistic view of emotions \\
\hline 2.402 & 11.81 & Relationship to higher values \\
\hline 3.634 & 7.90 & Controllability \\
\hline 2.275 & 4.46 & Numbness \\
\hline 3.137 & 13.47 & Rationality \\
\hline 2.337 & 6.61 & Duration of sever feelings \\
\hline 3.053 & 10.41 & Consensus \\
\hline 3.261 & 9.79 & Acceptance \\
\hline 2.158 & 11.01 & Rumination \\
\hline 2.064 & 8.40 & Expression \\
\hline 2.533 & 6.78 & Blame \\
\hline & & \\
\hline
\end{tabular}

According to the table, out of anxiety diss, rationality as empotional schema with 13.47 mean, high value schema with 11.81 mean and simplistic views of emotions are considered inefficient with 11.75 mean.

Based on obtained results from the tables, emotional schema of guilt in depressed people is different with whom they are not. In depressed people there is a self-criticizing that criticizes being depressed. Thus cause them to have sense of guilt about themselves [29]. Sense of guilt is not related only to their thoughts and events of their environment but it is related to their emotions. They believe that a person is not supposed to have special emotions and they all believe that their all feelings are wrong. So they think that their emotions are different with other people and people have to accept their difference [20]. 
Вісник післядипломної освіти. Випуск 7(36) «Серія «Соціальні та поведінкові науки» https://doi.org/10.32405/2522-9931

Emotional schemas of validation by others and comprehensibility in depressed people is different with not depressed individuals. Validation by others schemas means that these type of person want people approve their emotion. Depressed people think that other people cannot understand them and accept their different emotions. So they always have sense of guilt and shame about their emotions. This sense of shame and guilt cause them that people don't approve them. So validation by others schemas has no direct role in depression but this sense of guilt and not being comprehensive is a depressed people feeling that can indirectly have effect on depression. So difference in this schema can be observed in depressed and not depressed people [20]. Cognitive schema of attachment/ incompetence when people think that they are incompetent of cannot fulfill their duties without people help they feel miserable. Depressed people continuously think that they are stupid and incompetent so they think they have to obey other people. Thus, there is difference between attachment/ incompetence and obedience of depressed people and not depressed ones. [19] Not only represent attachment/ incompetence schema s potential anticipator of depression sign exposure but also point that this schema can make people depressed when it is along with sense of guilt and shame. People that are exposed to these both schema they are more prone to be depressed. Results of this study and researches of Vai zadeh, mehrabi Zadeh, Honarmand (2010), Tabatabaie, Barzaki, Soohrabi, Karimi Zarchi (2010), Kurmear and Jurda and Walberck and Kalhan (2012), Ashley, Haris, Cartine (2002) reported attachment/ incompetence and fault/shame schemas besides other schemas.

Results of this study reported that there is difference between cognitive schemas of failure and unrelenting standards/ hypercriticalness among depressed and not depressed people. This difference is indicates that depressed person have hypercritical standards for himself and has not fair attitude toward himself/herself (unrelenting standards/ hypercriticalness). So he/she feels desperate and he thinks that each happens will be failed. He/she defeated and feels responsible for his/her failure. Then she/he feels that he/she is inferior, incompetent, incapable and do not have required competence for different contexts of life [2]. At result, in order to change different aspect of life they feel powerless (Tube, Schiff, and Love, 2008). This forms failure cognitive schemas. Nevertheless big dreams and unrelenting standards schemas can cause a person to feel that he/she deserves the best and thinks of excessive self-assertion. This can form efficacy schema/ high-mindedness. Results of the study were compatible with Camera and Okaloit (2012), Vali Zadeh, Hasan vandi, and Mehrabi Zadeh Honarmand (2010), Izadian, Dolatshahi, Mohammad Khani, Pour Shahbaz (2010).

Based on the results of the tables, difference of emotional schemas in anexiety disorders, emotional schemas including comprehensibility, guilt, simplistic view of emotions, controllability, consensus with people, accepting feelings, rationality, rumination and blame have been observed in people with anxiety which approves 
relation of this schemas with anxiety. Results of other researches (outdoor researches) indicated that comprehensibility, guilt, simplistic view of emotions, controllability, consensus with people, accepting feelings, rationality, rumination and blame have role in creation of anxiety disorders [20]. In general explanation of how these schemas has role in creation of anxiety disorders we can state that when people feel anxiety they try to express their feelings to other people because based on definition of validation by others emotional schema they think that people share their feelings but that is not so and they receive responses in contrast to what they expected. Therefore when they do not see consensus with others they try to avoid share their feelings. And when they are emotional try to rationally interpret the situation and they think their emotions need to be justified rationally (rationality emotional schema). People with anxiety disorders in some situations wants people to approve their feelings and emotions but when they don't receive their validation they feel people cannot understand them (comprehensibility, and they believe their emotions are not accepted by people and they have low consensus finally they cannot justify this condition rationally so they feel guilty (guilt). This sense of guilt cause them not to accept their feelings and their emotions (fillings acceptance). One strategy is blaming people (Blaming others as an emotional schema). Consequently they are permanently looking for answering many questions about their difference with other people and they do not find any reply (rumination as an emotional schema) [20].

Patients that their schemas is in disconnection and rejection, they cannot experience secure and satisfiable attachments with people. These individuals believe that their needs to security, love, kindness, and fixation would not be met. Their families is usually instable, heartless, rejecting or isolated. These patients hurt most. Most of them has had shocking childhood and when they get older they make irrational and hasty in shifting from one harmful relationship to other one and in avoiding relationships. Patients with abandonment/Instability schema believe that their relationship with main people in their life is not stable and they feel that they would not stay in their life because they are unpredictable emotionally. They feel people presence in their life is temporary and may be they die or abandon them when they are ill. Patients with emotional deprivation schema do not expect that their interest at having emotional relationship with people is satisfied enough (Young, et al).

\section{CONCLUSIONS AND PROSPECTS FOR FURTHER RESEARCH / ВИСНОВКИ ТА ПЕРСПЕКТИВИ ПОДАЛЬШИХ ДОСЛІДЖЕНЬ}

Anxiety and depression disorders are the most prevalent disorders that which cause considerable disorders, overusing sanitation care services and hyperactivity disorder. Based on cognitive perspective it is mental damage caused by creation and 
stability of early maladaptive schemas and patterns of habitual thinking is very popular and comprehensive that identify vulnerability kind.

In cognitive schemas contexts in all levels of anxiety disorders, all domains of cognitive schema are inefficient specially disconnection and rejection Domain. Emotional schemas of depressed people were analyzed and indicated that emotional schemas of guilt and validation by others are dominant pattern in explanation of depression disorders. Out of cognitive schemas, dependence/incompetence cognitive schemas and unrelenting standards / hypercritical can anticipate depression.

It seems expedient to training clinical psychologists to work with persons with depressive and anxiety disorders based on the study of their dominant cognitive and emotional schemes. Such training can be carried out both in the process of training psychologists in institutions of higher education, and in conditions of postgraduate education

Prospects for further research. Further studies of all DSM disorders, special studies on patterns for personality disorders, evaluating parental schemes and the effect of schema therapy on disorders, are needed in the future. It seems expedient to investigate the readiness of clinical psychologists to provide psychological help to people with depressive and anxiety disorders based on the study of their dominant cognitive and emotional schemes.

\section{7. СПИСОК ВИКОРИСТАНИХ ДЖЕРЕЛ / REFERENCES (TRANSLATED AND TRANSLITERATED)}

[1] B.Sadok, V.Sadok, Clinical psychological instruction of Kapllan and Sadok; translated by Ali Mokhtari Amir Amjadi et al. Tehran: Teymour Zadeh, 2009.

[2] E. Martine Seligman, D. Rooznahan, Psychological pathology, first volume; translated by Yahya Seid Mohammadi. Tehran: Arasbaran, 1987.

[3] I. Gotlib, C. Hammen, «Handbook of depression. Second edition», The Guiford press. New York, London, 2009.

[4] A. Beck, Social Interest: A Challenge to mankind. New York: The Guilford Press, 1976.

[5] L. Greenberg, L. Rice \& R. Elliott, Facilitating emotional change: The moment by - moment process. New York: Guilford Press, 1983.

[6] J. Allen, «Coping with depression», American Psychiatric Publishing, Inc. 2006.

[7] E. Ashley, A. Harris \& L. Curtin, «Parental perceptions, early maladaptive schemas, and depressive symptoms in young adults», Journal of Cognitive Therapy and Research, № 26, p. 405-416, 2002.

[8] A. Beck \& Associates, Cognitive Therapy of Personality Disorders (2nd ed). New York: The Guilford Press, 2004. 
Вісник післядипломної освіти. Випуск 7(36) «Серія «Соціальні та поведінкові науки» https://doi.org/10.32405/2522-9931

[9] Cámara M.r. Calvete, Esthe, «Early Maladaptive Schemas as Moderators of the Impact of Stressful Events on Anxiety and Depression in University Students», Journal of Psychopathology and Behavioral Assessment, № 34, p. 58-68, 2012.

[10] A. Beck, A. Freeman \& et.al., Cognitive Therapy for personality disorders. New York: Guilford Pres, 1990.

[11] A. Freeman \& G. Fusco, Borderline personality disorder - $A$ therapists guide to taking control. USA: Norton, 2004.

[12] A. Hakan \& D. Karahan \& M. Caliskan, «Early maladaptive schemas activated in patients with obsessive compulsive disorder: A cross-section a study», International Journal of psychiatry in clinical practice, № 12, p. 268-279, 2008.

[13] J. Young, J. Klosko \& M. Weishaar, Schema Therapy A Practitioner's guid. New York: Guilford Press, 2003.

[14] J.Young \& M. Lindemann, «An integrative schema-focused model for personality disorders»; In: R. L. Leahy \& E. T. Dowd (Eds.), Clinical advances in cognitive psychotherapy: theory and application. New York: Springer Publishing, p. 93-109, 2002.

[15] J. Young \&, G. Brown, Young Schema Questionnaire: Special Edition. New York: Schema Therapy Institute, 2001.

[16] J.Young, Cognitive therapy for personality disorders: A Schema-focused approach. Sarasota, FL: Professional resource exchange, Inc, 1990.

[17] J. Young, Young Parenting Inventory. New York: Cognitive Therapy. Center of New York, 1994.

[18] J.Young, Young Schema Questionnaire Short Form. New York: Cognitive Therapy Center, 1998.

[19] J. Young, Cognitive Therapy for personality disorders: A Schema Focused approach. Sarasota, FL: Professional Resourse Press, 1999.

[20] R. Leahy, «A model of emotional schemas», CognBehavPrac, № 9, p. 177-190, 2002.

[21] R. Leahy, «Emotional schemas and resistance to change in anxiety disorders», CognBehavPract, № 14, p. 36-45, 2007.

[22] A.Wells, «Emotional Disorders and Metacognition: Innovative Cognitive Therapy. West Sussex: Wiley, John \& Sons», Journal of Social Issues \& Humanities, Volume 2, Issue 4, April, p. 55-73, 2014. ISSN 2345-2633

[23] R. Leahy, Roadblocks in Cognitive-Behavioral Therapy: Transforming Challenges into Opportunities for Change. New York: The Guilford Press, 2003.

[24] B. Sadock, \& V. Sadock, Kaplan and Sadock's Synopsis of Psychiatry. Tehran: Teymourzadeh, 2009.

[25] P.Dadsetan, Transformational Pathological psychology from childhood to adulthood. 1st ed. Tehran: Samt, 2007. 
Вісник післядипломної освіти. Випуск 7(36) «Серія «Соціальні та поведінкові науки» https://doi.org/10.32405/2522-9931

[26] Askari, Hamideh, «Evaluation of emotional and cognitive schemas in depressed and non-depressed students», Master Thesis «Clinical Psychology»; Islamic Azad University, Science \& Research, 1932.

[27] Ensieh Bakhtiari, «The role of early maladaptive schemas in explaining anxiety disorders», Master Thesis «Clinical Psychology»; Islamic Azad University, Science \& Research, 1932.

[28] R. L. Leahy, D. Tirch, L. A. Napolitano, Emotion Regulation in Psychotherapy: A Practitioner's Guide. New York: Guilford Press, 2011.

[29] Cognitive Behaviour Therapy for Psychiatric Problems; Edited by Keith Hawton, Paul. M. Salkovskis, Joan Kirk, and David M. Clark New York: The Guilford Press, 2010.

\section{ДОМІНАНТНІ КОГНІТИВНІ ТА ЕМОЦІЙНІ СХЕМИ ПРИ ДЕПРЕСИВНИХ ТА ТРИВОЖНИХ РОЗЛАДАХ}

\section{Сурена Сардарзаде,}

аспірант кафедри психодіагностики

та клінічної психології факультету психології

Національного університету імені Тараса Шевченка,

Київ, Україна.

soorena.sardarzadeh@gmail.com

Анотація. Тривожні і депресивні розлади $є$ найбільш поширеним типами розладів, які викликають значні порушення, перенапруження i гіперактивність. Використання когнітивної перспективи для аналізу цих психічних порушень, викликаних створенням і стабілізацією ранніх дезадаптивних схем i зразків когнітивних звичок $\epsilon$ дуже розповсюдженим і всебічним підходом до ідентифікації порушень цього типу. Була проведена значна кількість досліджень причин виникнення тривожних i депресивних розладів, це дослідження також $\epsilon$ спрямованим на вивчення ролі домінантних когнітивних і емоційних схем при депресивних i тривожних розладах. Це дослідження $\epsilon$ дослідженням причинно-порівняльного типу, в ньому взяли участь 109 осіб, які страждають від різних типів тривожних розладів і 208 пацієнтів, що страждають від депресивних розладів. Стан пацієнтів оцінювався відповідно до результатів напівструктурованих інтерв'ю на основі DSMIV-TR, (SCID-I) розроблених Янгом ранніх дезадаптивних схем (скорочена форма) і шкали емоційних схем Лixi (LESS - Leahy emotional schema Scale). Для аналізу данних був використаний метод спрямованого дисперсійного аналізу. Згідно 3 отриманими результатами емоційні схеми відіграють значну роль у створенні всіх типів тривожних розладів. Однак, раціональна емоційна схема не відіграє ніякої ролі у виникненні соціофобних розладів, 
персоніфікованих фобії, обсесивно-компульсивних розладів і тривожних розладів. У контекстах когнітивних схем на всіх рівнях тривожних розладів, в усіх доменах когнітивних схем присутня домінанта певної втрати зв'язку і відчудження. Аналіз емоційних схеми пацієнтів 3 депресивними розладами показав, що емоційні схеми провини i схвалення з боку інших $\epsilon$ домінантними моделями для пояснення депреивних розладів. Наявність когнітивних схем залежності / некомпетентності і завищених стандартів, нездатності до компромісів / надмірно критичного ставлення, можуть бути передвісниками депресії. Констатовано доцільність підготовки клінічних психологів до роботи 3 особами з депресивними та тривожними розладами на базі вивчення їх домінантних когнітивних та емоційних схем. Такі підготовку слід здійснити як у процесі навчання психологів у закладах вищої освіти, так і в умовах післядипломної освіти.

Ключові слова: депресивні розлади; емоційні розлади; когнітивні схеми Янга; шкала емоційних схем Ліхі; ранні дезадаптивні схеми.

\section{ДОМИНАНТНЫЕ КОГНИТИВНЫЕ И ЭМОЦИОНАЛЬНЫЕ СХЕМЫ ПРИ ДЕПРЕССИВНЫХ И ТРЕВОЖНЫХ РАССТРОЙСТВАХ}

\section{Сурена Сардарзаде,}

аспирант кафедры психодиагностики

и клинической психологии факультета психологии

Национального университета

имени Тараса Шевченка,

Киев, Украина.

soorena.sardarzadeh@gmail.com

Аннотация. Тревожные и депрессивные расстройства являются наиболее распространенными типами расстройств, которые вызывают значительные нарушения, перенапряжение и гиперактивность. Использование когнитивной перспективы при анализе этих психических нарушений, вызванных созданием и стабилизацией ранних дезадаптивных схем и образцов когнитивнных привычек, является очень распространенным и всеобъемлющим подходом к идентификации нарушений подобного типа. Было проведено значительное количество исследований причин возникновения тревожных и депрессивных расстройств. Данное исследование также является направленным на изучение роли доминантных когнитивных и эмоциональных схем при депрессивных и тревожных расстройствах. Данное исследование является исследованием причинносравнительного типа, оно проведено на материале 109 человек, 
страдающих различными типами тревожных расстройств и 208 пациентов, страдающих депрессивными расстройствами, состояние пациентов оценивалось по результатам полуструктурированных интервью на основе DSM-IV-TR, (SCID-I) разработанных Янгом ранних дезадаптивных схем (сокращенная форма) и шкалы эмоциональных схем Лихи (LESS - Leahy emotional schema Scale). Для анализа данных был использован метод направленного анализа дисперсии. Согласно полученным результатам, эмоциональные схемы играют значительную роль в создании всех типов тревожных расстройств. Однако, рациональная эмоциональная схема не играет какой-либо роли в возникновении социофобних расстройств, персонифицированных фобий, обсессивно-компульсивных расстройств и тревожных расстройств. В контекстах когнитивных схем на всех уровнях тревожных расстройств, во всех доменах когнитивных схем присутствует доминанта определенной потери связи и отчуждения. Анализ эмоциональных схемы пациентов с депрессивными расстройствами показал, что эмоциональные схемы вины и одобрения со стороны других являются доминантными моделями для объяснения депресивних расстройств. Наличие когнитивных схем зависимости/ некомпетентности и завышенных стандартов / чрезмерно критического отношения могут быть предвестниками депрессии.

Констатирована целесообразность подготовки клинических психологов к работе с лицами с депрессивными и тревожными расстройствами на базе изучения их доминантных когнитивных и эмоциональных схем. Такую подготовку можно осуществить как в процессе обучения психологов в учреждениях высшего образования, так и в условиях последипломного образования.

Ключевые слова: депрессивные расстройства; эмоциональные расстройства; когнитивные схемы Янга; шкала эмоциональных схем Лихи; ранние дезадаптивные схемы.

\section{СПИСОК ВИКОРИСТАНИХ ДЖЕРЕЛ}

[1] Б. Садок, В. Садок, Клінічне психологічне навчання Каплана і Садока; пер. Алі Мохтарі Амір Амджаді та ін. Тегеран: Теймур Заде, 2009.

[2] М. Селігман, Д. Роознан, Психологічна патологія, т. 1, пер. Ях'я Сейд Мохаммаді. Тегеран: Arasbaran, 1987.

[3] I. Готліб, К. Хаммен, «Довідник про депресії. Друге вид. Преса Guiford. Нью-Йорк, Лондон, 2009.

[4] А. Бек, Соціальний інтерес: виклик людству. Нью-Йорк: прес Гілфорд, 1976. 
Вісник післядипломної освіти. Випуск 7(36) «Серія «Соціальні та поведінкові науки» https://doi.org/10.32405/2522-9931

[5] Л. Грінберг, Л. Райс і Р. Елліотт, Сприяння емоційним змінам: процес від моменту до моменту. New York: Guilford Press, 1983.

[6] Дж. Аллен, «Справляючись 3 депресією», American Psychiatric Publishing, Inc. 2006.

[7] Е. Ешлі, А.Харріс і Л. Куртин, «Батьківські сприйняття, ранні неадаптивні схеми та депресивні симптоми у молодих людей», Журнал когнітивної терапії та досліджень, № 26, р. 405-416, 2002.

[8] A. Beck \& Associates, Когнітивна терапія розладів особистості. 2-ге вид. Нью-Йорк: Пресс Гілфорд, 2004.

[9] М.p. Камара, Calvete Esthe, «Ранні малоадаптивні схеми як модератори впливу стресових подій на тривожність і депресію у студентів університету», Журнал психопатології та поведінкової оцінки, № 34, р. 58-68, 2012.

[10] А. Бек, А. Фрімен та ін., Когнітивна терапія для розладів особистості. Нью-Йорк: Гілфорд Прес, 1990.

[11] А.Фрімен і Г. Фуско, «Прикордонний розлад особистості», Керівнищтво психотерапевтів для прийняття контролю. США: Нортон, 2004.

[12] А.Хакан, Д.Карахан і М. Каліскан, «Ранньонеадаптивні схеми, активовані у пацієнтів 3 обсесивно-компульсивним розладом: перетин дослідження», Міжнародний журнал психіатрії в клінічній практиці, № 12, р. 268-279, 2008.

[13] Я. Янг, Дж. Клоско і М. Вейшаар, Керівник схеми терапії. Нью-Йорк: Guilford Press, 2003.

[14] J. Young \& М. Ліндеманн, «Інтегративна схема, орієнтована на моделі розладів особистості»; У: Р. Л. Ліі і Е. Т. Доуд, Ред. Клінічні досягнення в когнітивній психотерапії: теорія і застосування. New York: Springer Publishing, 2002, p. 93-109.

[15] J. Young \& G. Brown, Анкета молодої схеми: Special Edition. Нью-Йорк: Schema Therapy Institute, 2001.

[16] Я.Янг, Когнітивна терапія для розладів особистості: підхід, орієнтований на схему. Sarasota, FL: Професійний обмін ресурсами, Inc, 1990.

[17] Ю.Янг, Інвентаризація молодих батьків. Нью-Йорк: Когнітивна терапія. Центр Нью-Йорка, 1994.

[18] Ю. Янг, Коротка форма анкети для молодої схеми. Нью-Йорк: Центр когнітивної терапії, 1998.

[19] J. Young, Когнітивна терапія для розладів особистості: підхід, орієнтований на схему. Сарасота, Флорида: Професійна преса, 1999.

[20] Р. Ліi, «Модель емоційних схем», CognBehavPrac, № 9, p. 177-190, 2002. 
Вісник післядипломної освіти. Випуск 7(36) «Серія «Соціальні та поведінкові науки» https://doi.org/10.32405/2522-9931

[21] Р. Ліi, «Емоційні схеми та стійкість до змін в тривожних розладах», CognBehavPract, № 14, p. 36-45, 2007.

[22] А Уеллс, «Емоційні розлади і метапознання: інноваційна когнітивна терапія. Західний Сассекс: Wiley, John \& Sons», Журнал соціальних питань та гуманітарних наук, т. 2, вип. 4, квітень, р. 55-73, 2014. ISSN 2345-2633

[23] Р. Ліi, Дорожні перешкоди в когнітивно-поведінковій терапії: перетворення викликів у можливості для змін. Нью-Йорк: Прес Гільфорд, 2003.

[24] Б. Садок \& В.Садок, Каплан і конспект психіатрії Садока. Тегеран: Теймурзаде, 2009.

[25] П. Дадсетан, Трансформаційна патологічна психологія від дитинства до дорослого віку. 1-е изд. Тегеран: Samt, 2007.

[26] Аскарі Хамідех, «Оцінка емоційно-когнітивних схем у депресивних та недепресивних студентів», магістерська робота «Клінічна психологія»; Ісламський університет Азад, Наука і дослідження, 1932.

[27] Енсєх Бахтіарі, «Роль ранніх малоадаптивних схем у поясненні тривожних розладів», магістерська дис. «Клінічна психологія»; Ісламський університет Азад, Наука і дослідження, 1932.

[28] Р. Л. Ліi, Д. Тірх, Л. А. Наполітано, Емоційне регулювання в психотерапії: керівництво практикуючих. Нью-Йорк: Guilford Press, 2011.

[29] Терапія когнітивної поведінки для психіатричних проблем; Кейта Hawton, Paul. M. Сальковськіс, Джоан Кірк та Девід М. Кларк, Ред. НьюЙорк: Пресс Гілфорд, 2010.

\section{REFERENCES (TRANSLATED AND TRANSLITERATED)}

[1] B.Sadok, V.Sadok, Klinichne psykholohichne navchannia Kaplana i Sadoka; per. Ali Mokhtari Amir Amdzhadi ta in. Teheran: Teimur Zade, 2009.

[2] M. Selihman, D. Rooznan, Psykholohichna patolohiia, t.1, per. Yakhia Seid Mokhammadi. Teheran: Arasbaran, 1987.

[3] I. Hotlib, K. Khammen, «Dovidnyk pro depresii». Druhe vyd. Presa Guiford. Niu-York, London, 2009.

[4] A. Bek, Sotsialnyi interes: vyklyk liudstvu. Niu-York: pres Hilford, 1976.

[5] L. Hrinberh, L. Rais i R. Elliott, Spryiannia emotsiinym zminam: protses vid momentu do momentu. New York: Guilford Press, 1983.

[6] Dzh. Allen, «Spravliaiuchys z depresiieiu», American Psychiatric Publishing, Inc. 2006.

[7] E. Eshli, A. Kharris i L. Kurtyn, «Batkivski spryiniattia, ranni neadaptyvni skhemy ta depresyvni symptomy u molodykh liudei», Zhurnal kohnityvnoi terapii ta doslidzhen, № 26, p. 405-416, 2002. 
Вісник післядипломної освіти. Випуск 7(36) «Серія «Соціальні та поведінкові науки» https://doi.org/10.32405/2522-9931

[8] A. Beck \& Associates, Kohnityvna terapiia rozladiv osobystosti. 2-he vyd. NiuYork: Press Hilford, 2004.

[9] M.r. Kamara, Calvete Esthe, «Ranni maloadaptyvni skhemy yak moderatory vplyvu stresovykh podii na tryvozhnist i depresiiu u studentiv universytetu», Zhurnal psykhopatolohii ta povedinkovoi otsinky, № 34, p. 58-68, 2012.

[10] A. Bek, A. Frimen ta in., Kohnityvna terapiia dlia rozladiv osobystosti. NiuYork: Hilford Pres, 1990.

[11] A. Frimen i H. Fusko, «Prykordonnyi rozlad osobystosti», Kerivnytstvo psykhoterapevtiv dlia pryiniattia kontroliu. SShA: Norton, 2004.

[12] A. Khakan, D. Karakhan i M. Kaliskan, «Rannoneadaptyvni skhemy, aktyvovani u patsiientiv z obsesyvno-kompulsyvnym rozladom: peretyn doslidzhennia», Mizhnarodnyi zhurnal psykhiatrii v klinichnii praktytsi, № 12, p.268-279, 2008.

[13] Ya.Yanh, Dzh. Klosko i M. Veishaar, Kerivnyk skhemy terapii. Niu-York: Guilford Press, 2003.

[14] J. Young \& M. Lindemann, «Intehratyvna skhema, oriientovana na modeli rozladiv osobystosti»; U: R. L. Lii i E. T. Doud, Red. Klinichni dosiahnennia v kohnityvnii psykhoterapii: teoriia i zastosuvannia. New York: Springer Publishing, 2002, p. 93-109.

[15] J.Young \& G. Brown, Anketa molodoi skhemy: Special Edition. Niu-York: Schema Therapy Institute, 2001.

[16] Ya. Yanh, Kohnityvna terapiia dlia rozladiv osobystosti: pidkhid, oriientovanyi na skhemu. Sarasota, FL: Profesiinyi obmin resursamy, Inc, 1990.

[17] Yu. Yanh, Inventaryzatsiia molodykh batkiv. Niu-York: Kohnityvna terapiia. Tsentr Niu-Yorka, 1994.

[18] Yu.Yanh, Korotka forma ankety dlia molodoi skhemy. Niu-York: Tsentr kohnityvnoi terapii, 1998.

[19] J. Young, Kohnityvna terapiia dlia rozladiv osobystosti: pidkhid, oriientovanyi na skhemu. Sarasota, Floryda: Profesiina presa, 1999.

[20] R. Lii, «Model emotsiinykh skhem», CognBehavPrac, № 9, p. 177-190, 2002.

[21] R. Lii, «Emotsiini skhemy ta stiikist do zmin v tryvozhnykh rozladakh», CognBehavPract, № 14, p. 36-45, 2007.

[22] A Uells, «Emotsiini rozlady i metapoznannia: innovatsiina kohnityvna terapiia. Zakhidnyi Sasseks: Wiley, John \& Sons», Zhurnal sotsialnykh pytan ta humanitarnykh nauk, t. 2, vyp. 4, kviten, p. 55-73, 2014. ISSN 2345-2633

[23] R. Lii, Dorozhni pereshkody v kohnityvno-povedinkovii terapii: peretvorennia vyklykiv u mozhlyvosti dlia zmin. Niu-York: Pres Hilford, 2003.

[24] B.Sadok \& V.Sadok, Kaplan i konspekt psykhiatrii Sadoka. Teheran: Teimurzade, 2009.

[25] P. Dadsetan, Transformatsiina patolohichna psykholohiia vid dytynstva do dorosloho viku. 1-e yzd. Teheran: Samt, 2007. 
[26] Askari Khamidekh, «Otsinka emotsiino-kohnityvnykh skhem u depresyvnykh ta nedepresyvnykh studentiv», mahisterska robota «Klinichna psykholohiia»; Islamskyi universytet Azad, Nauka i doslidzhennia, 1932.

[27] Ensiekh Bakhtiari, «Rol rannikh maloadaptyvnykh skhem u poiasnenni tryvozhnykh rozladiv», mahisterska dys. «Klinichna psykholohiia»; Islamskyi universytet Azad, Nauka i doslidzhennia, 1932.

[28] R. L. Lii, D. Tirkh, L. A. Napolitano, Emotsiine rehuliuvannia v psykhoterapii: kerivnytstvo praktykuiuchykh. Niu-York: Guilford Press, 2011.

[29] Terapiia kohnityvnoi povedinky dlia psykhiatrychnykh problem; Keita Hawton, Paul. M. Salkovskis, Dzhoan Kirk ta Devid M. Klark, Red. Niu-York: Press Hilford, 2010. 